\title{
Janne Lahti. Cultural Construction of Empire: The U.S. Army in Arizona and New Mexico.
}

\author{
Catharine R. Franklin
}

\section{(2) OpenEdition}

\section{Journals}

Electronic version

URL: https://journals.openedition.org/ejas/10259

DOI: 10.4000/ejas.10259

ISSN: 1991-9336

\section{Publisher}

European Association for American Studies

Electronic reference

Catharine R. Franklin, "Janne Lahti. Cultural Construction of Empire: The U.S. Army in Arizona and New Mexico.", European journal of American studies [Online], Book reviews, document 5, Online since 17 February 2014, connection on 31 August 2022. URL: http://journals.openedition.org/ejas/10259 ; DOI: https://doi.org/10.4000/ejas.10259

This text was automatically generated on 31 August 2022.

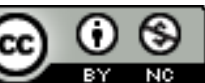

Creative Commons - Attribution-NonCommercial 4.0 International - CC BY-NC 4.0

https://creativecommons.org/licenses/by-nc/4.0/ 


\title{
Janne Lahti. Cultural Construction of Empire: The U.S. Army in Arizona and New Mexico.
}

\author{
Catharine R. Franklin
}

\section{REFERENCES}

Lincoln: University of Nebraska Press, 2012. Pp. 360. ISBN: 978-0-8032-3252-5

1 In the United States, the history of the military in the nineteenth-century American West is not much remarked by scholars. The conference programs of the American Historical Association and Organization of American Historians rarely feature the subject, and at the recent annual meeting of the Western History Association, only two panels out of eighty dealt with the topic. Most academic historians there turned instead to issues of race, class, gender, borderlands, and transcultural studies. Popular interest in narratives featuring Crazy Horse, George Armstrong Custer, and other figures has yet to wane, though, and one or two university presses continue to supply the demand for biographies of native leaders and army officers, as well as studies that center around conflict-based narratives of battle or massacre. While this work can be interesting, it reflects little engagement with the categories of analysis that preoccupy others in the discipline; with very few exceptions, there are no imaginative, broadly conceived histories likely to move the study of the U.S. Army in the West beyond where it was left twenty-five years ago by Robert Wooster's The Military and United States Indian Policy (1988) and Sherry Smith's The View from Officers' Row (1990). As the publication dates of these books suggest, the field is long overdue for an update.

2 At first glance, Cultural Construction of Empire: The U.S. Army in Arizona and New Mexico seems to be a book with some promise. The author, currently a postdoctoral researcher at the University of Helsinki, employs a postcolonial framework to explain how the army distorted cultural representations of themselves and native peoples in 
order to control Apaches in the Southwest. Lahti points out that military historians have yet to embrace discourses of power or acknowledge the destructive legacy of colonialism. Situating the work from a vantage point that is distinct from existing scholarship, the author seems poised to make a clear contribution to the field.

3 Cultural Construction of Empire begins with a brief overview of the transformation from Apacheria-the homeland of the native peoples at the center of the book-to the colonial administration established by the United States. Three subsequent chapters deal with Anglo-American officers, enlisted men, and their wives, and the ways in which they perceived themselves in opposition to the landscape of Arizona and New Mexico and the people who lived there. In these chapters, Lahti explains that army officers and their spouses, desperate to preserve their connections to the "civilized" eastern United States, used a rhetoric of cultural difference to explain the hardships that they encountered. In their correspondence and personal narratives, AngloAmericans perceived native spaces as a desolate, ugly, and forbidding wilderness. In order to juxtapose themselves with non-white peoples, they drew attention to the strangeness of the environment. At the same time, by portraying the southwest as a barren place, army officers and their wives justified the seizure of the Apache homeland.

4 Military life-both the middle-class aspirations of officers and their wives, and the working-class drudgery of enlisted men-is detailed in chapters 5 and 6 . Here the author echoes Class and Race in the Frontier Army (Norman: University of Oklahoma Press, 2009) in which Kevin Adams suggested that the strict class segregation defined the army in the post-Civil War era. For both Adams and Lahti, members of the officer corps were self-aggrandizing elites, eager to display their middle-class values through their living spaces and leisure pursuits. The two authors also agree that officers marginalized enlisted men who were treated little better than beasts of burden during their time in service. While these two chapters of Cultural Construction of Empire diverge from borderlands and transcultural themes, they nonetheless attempt to situate the army within nineteenth-century society.

5 Two other chapters deal with native peoples directly: chapter 4 ("Apaches in White Army Minds") and chapter 7 ("Colonized Labor"). The first chapter investigates army attitudes toward native peoples, including the Apaches and the Akimel O'odham (commonly known as the Pimas). Lahti asserts that army officers and their wives sought to make the Apaches "monstrous others," justifying their subjugation by contrasting cultural difference that, in reality, did not exist (111). Apaches were made out to be grotesque savages, compared to predatory animals, and described in degrading, racist terms. The author notes that historians, in describing native peoples as "hostile," have implicitly privileged colonial knowledge and perspectives by parroting the vocabulary of nineteenth-century Anglo-Americans. Rather than focus on the events that constituted the army's conquest of the Apaches, Lahti is concerned with the ways in which "army texts were about strengthening the privilege of whiteness and Anglo civilization" and the manner in which soldiers justified imperial agendas by vilifying native peoples.

6 Lahti's work is at its most interesting in the chapter on colonized labor, for here he has uncovered the story of Apaches who worked for the army. Whether serving as soldiers, scouts, or menial laborers, these men "proved able to use the . . labor system for negotiating the impact of colonialism" (218). Apache men received the same pay as 
white and black enlisted men, and some successfully applied for military pensions. Yet these workers were cast aside in the 1880s when the federal government forced them to move to Florida, and later Oklahoma.

7 Cultural Construction of Empire constitutes the first attempt to engage long-standing trends in Western and indigenous history by applying a postcolonial and transcultural framework to the study of native-military relations. Yet that alone is not enough to make Lahti's argument convincing. Certainly, the book will pass muster with scholars who are not familiar with the topic, and they will find it attractive because the author upholds the orthodoxy with which most non-military historians view the army-as an instrument of empire solely bent on colonizing, segregating, and harming non-white peoples.

8 Academic historians who deal with the history of the nineteenth-century army, however, will find this book sorely lacking. While Lahti acknowledges that the army was "never monolithic" in its ideas, he does not engage the diversity of opinions among soldiers and officers that other historians, including Sherry Smith, have identified. He makes questionable assertions, including the idea that the army was "loathed by the general public" (35) and seen as "unnecessary and unwanted in the East" (37). How does this view square with the dozens of Harper's Weekly articles that celebrated the role played by the frontier army in expanding national infrastructure, and, indeed, fighting Indians? For that matter, how to explain the widespread popularity, in the late nineteenth century, of personal narratives such as George Amstrong Custer's My Life on the Plains (1874), his wife's Boots and Saddles (1885), or the memoirs written by officers such as John Gregory Bourke? The answer is that Anglo-American civilians, not just soldiers, clung to the binaries of "civilization" and "savagery" that they had helped create in the nineteenth century. Other wrong-headed ideas mar the book. "Prison camp-like reservations" hardly describes the situation on the northern plains, where the Lakota people constantly crossed porous reservation boundaries to visit relatives elsewhere. The text omits to state the cause of the 1871 Camp Grant Massacre, which was the work of civilians, and makes it seem as if the army might have been involved, which it was not. And in portraying officers and their wives as elitists, the author seems to forget that the commander of a regiment, then as now, has to deal with the work of supervising hundreds of other men, and might be forgiven if he is not inclined to carry his own bags and trunks.

9 The most serious failings of the text lie in its devotion to postcolonial theory and also in the limited primary source base. Lahti cites some two dozen unpublished sources held at the Arizona Historical Society and the University of Arizona, as well as a handful of sources held elsewhere. As a result, in re-creating army representations of native peoples, he tends to rely on published memoirs and reminiscences that were calculated to appeal to Americans in the Gilded Age. Like Kevin Adams, Lahti does not consult the records of the United States Army, housed in the National Archives of Washington, DC. Nor does he cite the records of the Adjutant General's Office (the army's administrative branch), which are available on some two thousand rolls of microfilm. Had the author investigated these unpublished sources, he would have discovered that the army's dealings with native peoples were complex, contradictory, and not at all indicative of a simplistic desire for conquest. Army officers did more than fight Native Americans; they fed them, protected them from settlers, and argued on their behalf. While this seems counterintuitive, archival evidence supports the idea that army officers, from 
the northern to the southern plains, often criticized coercive Indian policies. Their dissent, in turn, provided spaces for native peoples to defy Anglo-Am aims in different ways. Finally, for a book that uses a postcolonial framework, there is little native voice, except for one chapter.

In asserting that the army clung to notions of native savagery, Cultural Construction of Empire is not far removed from the sort of work it seeks to criticize. And by imposing a postcolonialist framework on sources, the author forces the evidence to fit the theory, rather than letting the evidence (limited as it is in this particular book) speak for itself. Furthermore, the "social reading" of sources ignores individual agency, thus masking army officers' very real dissent. Until scholars choose to tackle the considerable body of primary sources left by the army itself, the complicated history of the institution and its tangled relationship with native people will remain unwritten.

\section{AUTHOR}

\section{CATHARINE R. FRANKLIN}

Department of HistoryUniversity of Tennessee at Chattanooga 